\title{
Culture, art and power at tulato in the pacific coast of Colombia and Ecuador
}

\begin{abstract}
This article draws on contemporary theory and practice to interpret pre-Hispanic developments on the southern Pacific coast of Colombia, especially among the Tumaco-La Tolita peoples whose boundaries extended as far as present-day Esmeraldas in Ecuador. It sets out to examine pre-Hispanic culture from various relevant points of view, using art and power as the basis of interpretation to infer the cultural, social and political character of these communities. These were hierarchical societies which expanded and exploited their broad dominions to extend their connections and exchange networks to distant coastal and inter-Andean regions. An attempt will be made, in the light of archaeological theory and evidence, to analyse the importance of culture, art and power in Tumaco-Tolita region. These peoples are also known as Tulato, a contraction of the original term which will be used here to refer to the chiefdoms (cacicazgos) of this coastal region.
\end{abstract}

Keywords: archaeology, tumaco-tolita, art, power, pacific coast, Colombia-Ecuador
Volume 5 Issue 3 - 2020

\section{Diógenes Patiño C}

Department of Anthropology, University of Cauca, Colombia

Correspondence: Diógenes Patiño C, Department of Anthropology, University of Cauca. Popayán, Colombia, Email dioptin@unicauca.edu.co

Received: February 26, 2020 | Published: June 25, 2020

\section{Introduction}

In this section contemporary theory and practice will be used to interpret pre-Hispanic developments on the southern Pacific coast of Colombia, especially among the Tumaco-La Tolita peoples whose boundaries extended as far as present-day Esmeraldas in Ecuador. It sets out to examine pre-Hispanic culture from various relevant points of view, using art and power as the basis of interpretation to infer the cultural, social and political character of these communities. These were hierarchical societies which expanded and exploited their broad dominions to extend their connections and exchange networks into distant coastal and inter-Andean regions. An attempt will be made, in the light of recent archaeological theory and evidence, to analyse the importance of culture, art and power in Tumaco-Tolita societies. These peoples are also known as Tulato, a contraction of the original term coined by A. Brezzi in 2003. The term will be used here to refer to the complex chiefdoms of this coastal region.

\section{The coastal landscape: mangrove swamp and riverine tropical forest}

The southern Colombian Pacific coast features flat, fertile, alluvial plains traversed by many rivers originating in the Western Cordillera of the Andes, or even the Central Cordillera as in the case of the river Patía which flows through the site of Hoz de Minamá. Leaving the steep Andean foothills behind, the rivers reach the alluvial plain: a strip of undulating terrain between 60 and $80 \mathrm{~km}$ wide, of Quaternary origin with some Tertiary hills. The vegetation still includes abundant tropical rain forest, especially in areas distant from the coastal urban centres of Tumaco, Iscuandé, Guapi, Timbiquí and Buenaventura. Beyond the firm plain are ecological and environmental zones much affected by the sea, with tidal flooding up to 8 metres deep reaching several kilometres inland. These fluctuations create ecological niches in areas known as natales, ${ }^{1}$ guandales, ${ }^{2}$ manglares (mangrove

${ }^{1}$ Areas of natos (Mora Megistosperma), trees associated with the lowland forested wetlands in the Pacific littoral of Colombia.

${ }^{2} \mathrm{~A}$ local name referring to marshy areas in the same region swamps) and playones, ${ }^{3}$ areas notable for extraordinary biodiversity in terms of faunal resources as well as tropical flora. The low-lying zones are naturally interconnected by an intricate network of swamps and canals, linking the sea with the alluvial plain via tributaries and major rivers such as the Mira, the Mexicano, the Caunapí, the Rosario and others (Figures 1\&2). This southern Pacific coastal region was the hub for extensive human settlements at various periods; however, the largest and most important occupation took place in pre-Hispanic times between 2.350 and 1,650 BP, with the cultures we know today as Tumaco-La Tolita.

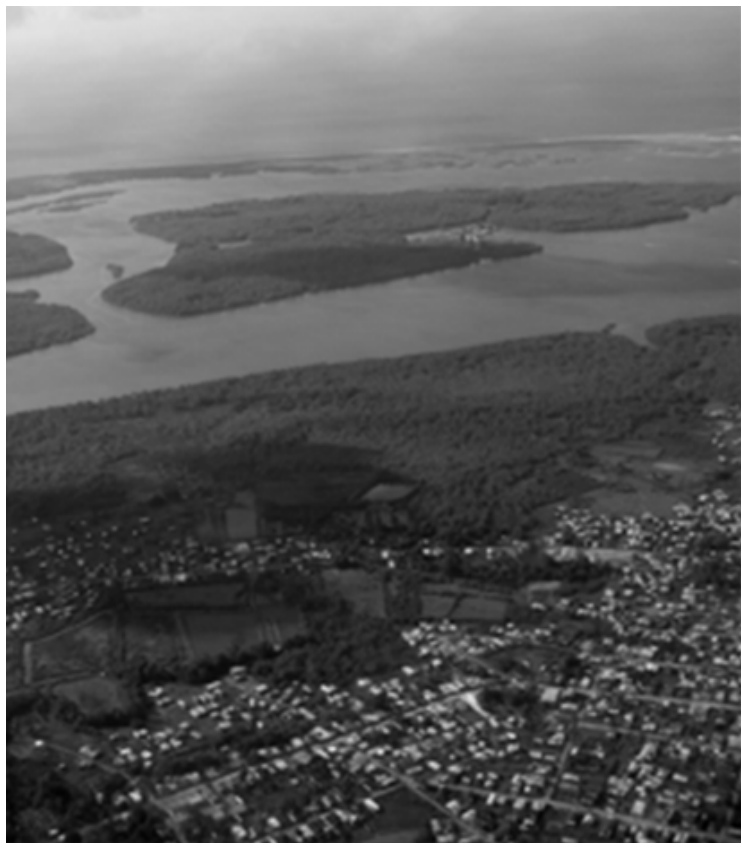

Figure I Tumaco. Marshes and Mangrove Swamps (photo author).

${ }^{3}$ Large or small sandy areas appearing on the coast at low tide. 


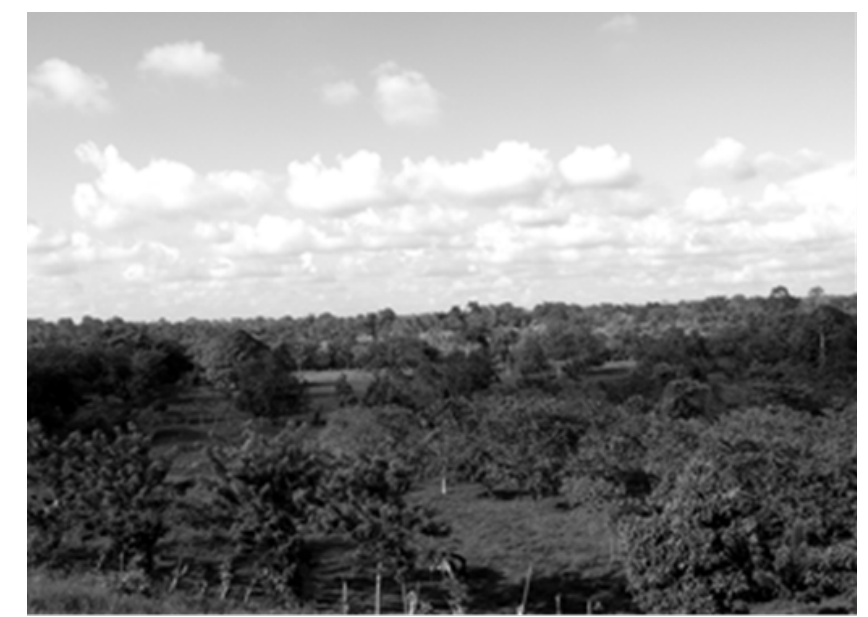

Figure 2 Alluvial plain near Tangareal, Tumaco (photo author).

\section{Pre-hispanic occupation and temporality on the pacific coast}

There are surprisingly few archaeological studies of the alluvial plains south of the Chocó, considering the great extent of the terrain, its importance during different periods of occupation and its closeness to the high Andean area. Despite this, it is possible to sketch a general archaeological map of the southern Pacific coast. The most ancient human occupations appear in equatorial zones, notably influenced by the Chorrera culture of Ecuador: people who understood seafishing and agricultural techniques as well as being highly skilled in metallurgy and ceramics. This influence appears to have reached what is now Colombian territory around 2.800 B.P., with settlements on the alluvial plain. These later gave way to important cultural and social transformations, resulting around ..350 B.P. in the peoples known as Tumaco-La Tolita: groups who attained levels of political, social and economic development unparallelled in the region or elsewhere in north-western South America. They were controlled by important caciques and shamans wielding great religious and political power throughout the coastal regions of Colombia and Ecuador.

Evidence from this area has also prompted a thesis of migration from parts of Mesoamerica, possibly resulting in fusion with existing cultures, either in the Chorrera period or later. ${ }^{1}$ This thesis has not been tested in depth; however, archaeological analogies between the two regions are startling and might be due to migrations caused by the high levels of volcanic activity prevalent in Central America, especially in Mexico, Guatemala, El Salvador and Costa Rica. In later periods many groups and settlements can be observed throughout the coastal lowlands of the Colombian Pacific; however, their political, social and economic structures in no way resemble those of the preceding cultures. Their traces seem rather to relate to tropical societies of the lowland forests and Andean piedmont, apparently under the leadership of minor local chiefs or caciques, some of whom were encountered at the time of the Conquest. Later still, the Pacific was subject to Spanish colonization which gradually assumed control of lands and communities for mineral exploitation, expecially in the province of Barbacoas (Nariño) and for the extraction of alluvial and vein gold in Cauca, Valle and Chocó. From the sixteenth to the eighteenth centuries groups of African slaves were brought in, more or less replacing the indigenous workforce which had been decimated by the colonial mines and haciendas. ${ }^{2,3}$

\section{The chiefdoms and their peoples}

It is justly considered that the cultural developments of the archaeological groups of south-western Colombia displayed a degree of political, social and economic organization equivalent to what are known as chiefdoms. These societies typically had relatively large populations settled in towns and villages over extensive territories, actively engaged in trading a variety of products over long and short distances. Communities included specialists in every kind of craft, especially goldwork, ceramics and the production of other objects requiring dedication and technological knowledge. It is also believed that these societies controlled the redistribution of surpluses among the population; arranged communal building projects; and successfully managed agricultural systems based on maize and other crops by organizing large workforces to construct and maintain raised fields, ditches and extensive drainage canals.

Social and power structures can be reconstructed from the evidence of material culture, particularly the sumptuary goods and ceramic and metal artifacts found in tombs, mounds and residential units. We infer that members of the elite had the means of acquiring superior objects (gold ornaments and beads of stone, shell and bone, for example) which also served as symbols of personal status. Equally, it is apparent that the demand for such goods stimulated craft production by specialists, as well as their exchange throughout extensive Andean and coastal areas. ${ }^{4-6}$ These theories are constantly reinforced by new archaeological discoveries providing ethnohistorical, ethnographical and environmental data in support of these cultures and their social, economic and political organization in south-western Colombia., ${ }^{3,7}$ This kind of cultural development on the Pacific coast of Colombia and Ecuador is expressed through archaeological evidence of the Tumaco-La Tolita culture, one of the most important in north-western South America.

\section{Chiefs, shamans and power in Tulato: art in clay and metal}

We can infer from various archaeological studies in the region that Tumaco and La Tolita featured important cultural developments indicative of hegemonic coastal chiefdoms, defined by a complex sociopolitical and economic unity and prospering between 2,350 and 1,650 B.P. along the Pacific coast of Colombia and Ecuador. ${ }^{8}$ During this period hierarchical societies dominated a huge coastal territory with settlements, mound cemeteries, agricultural fields and important advances in art and culture. Their scope was not merely local but extended into a broad system of regional interchange particularly characterised by short- and long-distance relationships within a circuit connecting the coast via the swamps and marshes, the alluvial plain and its rivers, with the Andean highlands of Ecuador and Colombia, where they obtained exotic products such as obsidian (volcanic glass) and other raw materials.

As noted above, there can be no doubt that the archaeological evidence for Tulato societies points to complex political and social division within their communities. This has been observed, for example, in excavations of domestic and funerary mounds, with variation in grave-goods and methods of burial; and also in metal art objects (gold, platinum and tumbaga) and hundreds and hundreds of anthropomorphic baked clay figurines which seem almost to be portraits, or realistic images, of the people who lived and interacted with one another in the coastal region. These objects have been widely 
publicised in the archaeological literature and through museums and collections of pre-Hispanic art in America and Europe. ${ }^{9-13}$

Studies of the ethnological symbolism of sculpture, aesthetics, iconography and the scenic representations resulting from cultural activities are important in defining the art of a culture as an expression of the system of values which govern it. From the perspective of Tumaco-Tolita sculpture we can distinguish two important elements of analysis, both involving consideration of the original ideas which motivated its artists:

(1) how they symbolically represented an act, a custom or a ritual; and

(2) how they produced works based on the human figure in order to create both images of people (portraits) and realistic daily scenes (life cycles and the human condition).

The creation of a human figure not only obeys the impulse to imitate the corporeal image; it also corresponds to the desire that this art object should fulfil a symbolic function associated with the prevailing cultural and social system. Figurative representations are in themselves vehicles for encoded messages which can be deciphered through semiotic analysis, bringing us closer to the original ideas of their makers and what they signified within the social, economic and political structure of a society. ${ }^{12}$ For M. Elíade, the symbolic is first and foremost a referent reality, because it represents nothing in itself, but establishes a close relationship between its meaning and historic reality; it reveals a true dimension but at the same time this is not immediate. Taking the foregoing into account, both conceptions - of the image and its symbolic function - are present in the figurative sculptural art of the Tulato, particularly as expressed in clay and metal. It is therefore possible to interpret the meaning of the human figure and its social and symbolic context within the boundaries of this archaeological community. There is in this culture an obsession with the human figure (portrait) charged with so much symbolism that we can believe ourselves to be in the presence of real characters from the past (Figures 3). This leads us into the presence of persons of different status and occupation such as chiefs, shamans, warriors, merchants, craftspeople and ordinary fishermen and farmers. As M.F. Ugalde has stated, the figurative objects of these cultures lead us to the reconstruction of a complex society with an active political life. ${ }^{12}$ In Tumaco there is a close relationship between persons of rank and the use of sumptuary objects such as ornaments and other items of gold, platinum and tumbaga, manufactured by specialist goldsmiths who supplied the demands and needs of a flourishing society. Various authors have suggested the existence of official specialists in such societies, employed either by the elites or by powerful organizations. This would ensure the supply, through exchange, of the raw materials needed for craftwork, the specialists becoming important exponents of the arts of clay, gold, shell and bone. The demand for these products created by social power structures influenced the specialist works and their patterns of exchange within the region; at the same time, it upheld, through the objects, the functional role of their symbolic, ritual and power-related elements. ${ }^{4,6}$

In Tulato societies the art of metallurgy appears early, around 2,400 B.P., in mound settlements such as La Magnolia (Chilví), located 15 $\mathrm{km}$ from the coast, where there are also extensive pre-Hispanic fields in the region of Inguapí and Chilví, near the Mirariver. Gold objects made with repoussé sheets and wire are found in anthropogenic soils with high concentrations of carbonized material, post-holes, human figurines, sherds, shells and fish-bones. These combined traces suggest activity areas where crafts such as goldworking developed.
Technological advances within this culture were quite varied. The goldsmiths were familiar with hammering, repoussé, granulation, oxidation gilding, filigree, the use of moulds and casting to produce series of ornaments, conglomerate by fusion, and lost-wax, among other techniques. They did not only work in gold, but also used silver, platinum and tumbaga to produce bimetallic pieces of high symbolic content. ${ }^{14}$ Knowledge of gold and clay working as a means of sculptural and symbolic expression was so important in Tulato that finds are distributed over a wide coastal area from Esmeraldas (Ecuador), Tumaco and Isla Gorgona to Isla Soldado and Bocana in the Bay of Buenaventura (Colombia). Throughout this huge region gold items (pendant plaques, buttons, filigree ornaments and fragments) are found in the same deposits as cultural materials of Tulato affiliation.
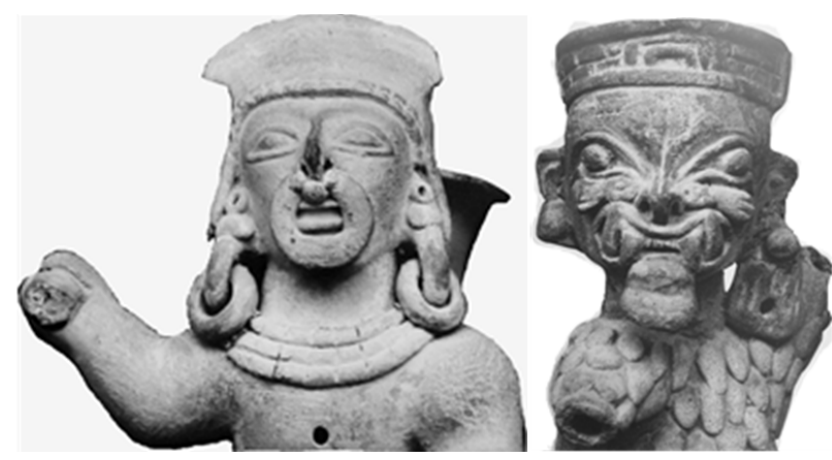

Figure 3 Tulato characters: "Chiefs" and "Shaman" (feathered jaguar). (Casa de la Cultura, Tumaco; Universidad Nacional).

In his metallographic studies Scott emphasizes the skill of these goldsmiths, whose considerable metallurgical advances enabled them to control the melting point of different types of gold alloy. ${ }^{15}$ Among other metal objects they made personal ornaments such as facial studs, nose-rings, earrings, pendants, beads, breast plates, diadems and dental incrustations. In some cases, these objects make up sets of ornaments, accompanied by precious stones such as jadeite, turquoise, agate and quartz. Some pieces were certainly of a ritual shamanic nature, including bells, jaguar-toothed masks, anthropomorphic and zoomorphic pectorals and assembled human figures, as well as clay figurines with gold ornaments. There are also needles, hooks and nails used to assemble larger pieces (Figure 4). Tumaco-Tolita metallurgy does not include the large birds with wings outspread, the heartshaped pectorals, nor the ' $H$-shaped' diadems indicative of a complex shamanic world, especially in the Andean societies of south-western Colombia. While most of the techniques and certain iconographic forms of the south-west are shared, Tumaco-Tolita goldwork forms a very particular entity, originating from complex coastal societies. ${ }^{16-19}$
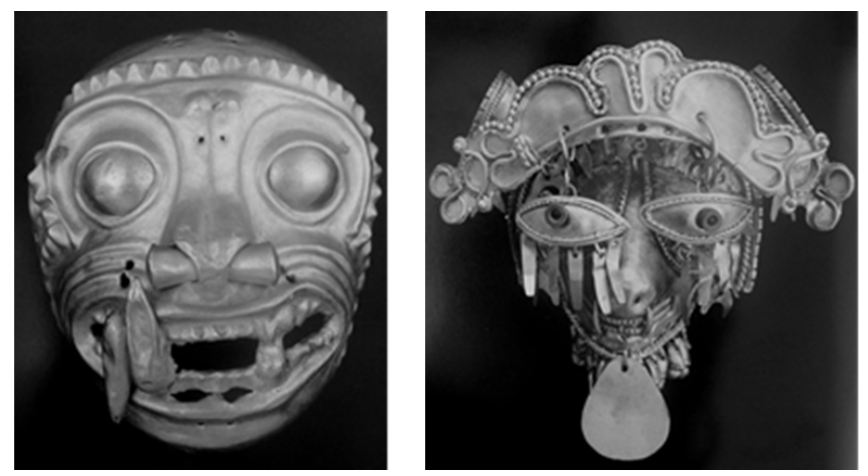

Figure 4 Ritual masks from Tumaco and La Tolita (I. Museo del Oro, Bogotá 2. Museo Nacional del Ministerio de Cultura, Quito). 


\section{Daily life in coastal Tulato}

Analysis of settlements in the region reveals concentrations of dwellings with mounds in fluvial areas with access to rivers, marshes, estuaries and the open sea, indicating exploitation of a range of natural resources according to the ecological zones under occupation. It is evident that during the most intensive settlement of Tulato, a time of great cultural vigour, almost all the available terrain was occupied: from the ecosystem of mangrove swamps and sea with its abundance of fish and shellfish, to the alluvial plain with its rich, fertile soils and forest products. This suggests that the inhabitants took the greatest possible advantage of the environmental resources available around their population centres. The settlements also suggest a complexity in the distribution, structure and function of these spaces, which were almost always under the power of caciques who occupied the largest and most central sites, close to productive agricultural lands. This seems to apply to the distribution of settlements in La Tolita, Inguapí, La Magnolia, La Catedral, Dos Quebradas and La Miranda on the Mira river. These sites include extensive areas of pre-Hispanic fields with central and satellite mounds, the spaces between them serving as streets. Smaller, scattered sites seem to correspond to the habitations of ordinary people, more dispersed but still connected to the overall system.

Settlements in the mangrove swamps suggest peoples living in pile-dwellings with access to abundant marine resources such as fish and shellfish. They were specialists in navigation and connected to the regional network of exchange. In the principal settlements the elites were able to mobilize labour for major mound-construction projects. These structures seem to have had a dual purpose:

(1) for the construction of important buildings for festivals, rites and the residences of rulers, and

(2) for burials, such as those seen at La Tolita, where urns and and pits containing assorted grave goods of shell, metal and pottery have been found. ${ }^{18}$

Clay model houses indicate architecture based on square, rectangular and circular plans, with adobe walls and wooden columns sustaining curved roofs of pitched wooden construction, very reminiscent of houses in the Far East (Polynesia). Some are profusely decorated with iconographic geometric designs, usually those communal houses intended for festivals and shamanic rites (Figure 5). ${ }^{20}$
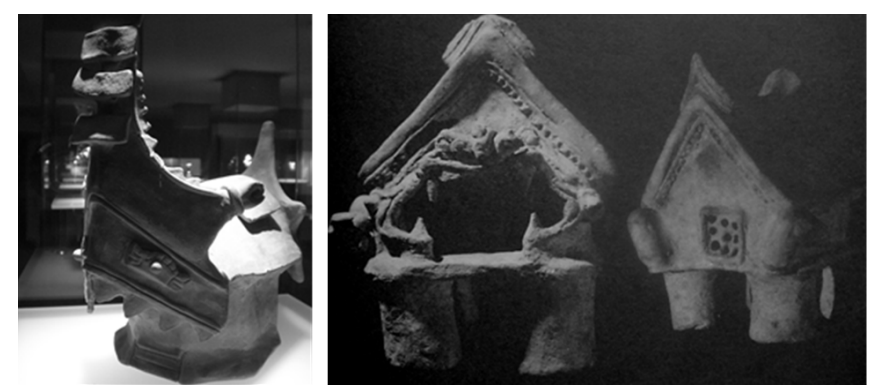

Figure 5 Models of Tumaco-Tolita ceremonial houses (I. Museo del Oro, Bogotá. 2. Wurster, 1989).

\section{Intensive agriculture, fishing, gathering and hunting}

One of the most notable characteristics of hierarchical societies is the management and control of subsistence resources, especially in the most productive areas generally occupied by major centres of economic and political power. The Tulato communities, like other societies of rank, succeeded in occupying and adapting the most fertile lands in the region for intensive agriculture, using a system of raised fields and canals. This success depended on efficient sociopolitical control and organization by the elites during the zenith and prosperity of their most important coastal centres, principally in the areas around La Tolita and Tumaco. The same applies to other parts of Esmeraldas and to Guayas province, where similar coastal chiefdoms developed. ${ }^{21,22}$ Archaeological studies in the region show that ancient raised fields covered extensive areas of 100 hectares or more. The execution of these massive agricultural projects suggests organized mobilization of labour, in order both to set up a system of raised fields and drainage and to feed a society with a constantly growing population. These areas of raised fields have in many cases been only partly discovered, the indication being that their dimensions are greater and still unknown. Raised fields were constructed in the lowest parts of the alluvial plain between 4 and 8 metres above sea level, making them vulnerable to periodic tidal inundations as well as the annual cycle of coastal rainy seasons. There are other sites, like La Tirsa (S59) and El Gran Cebú (S06) with raised fields between 15 and 50 metres above sea level, also in flat areas prone to flooding. Near La Tolita similar agricultural fields are found at La Laguna de la Ciudad. It is evident that during the Tulato period agricultural production increased with the new techniques (e.g. raised fields and drainage ditches) making it possible to support the significant growth in population with its consequent increase in the size of settlements and contact networks (Figures 6).
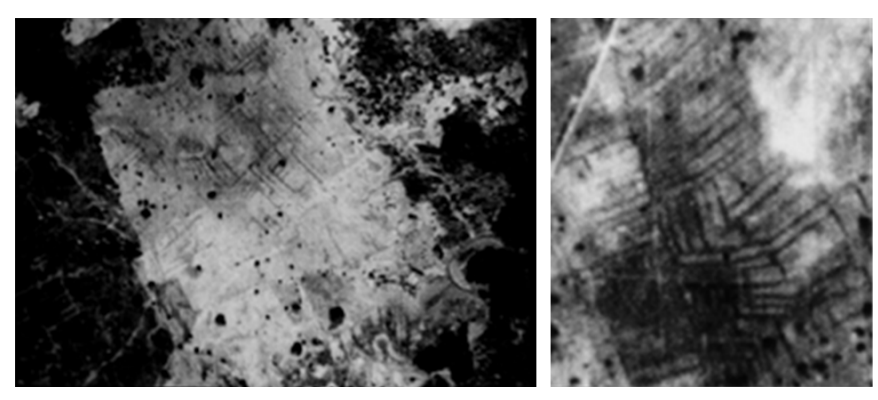

Figure 6 Agricultural zone. Piñal Salado (Tumaco). Drainage ditches and raised fields in Chilví-Inguapí.

Studies of pollen, phytoliths and macro-remains from preHispanic agricultural fields in Tumaco report the presence of various cultigens, particularly large quantities of maize (Zea mays), squash (Curcubita) and two species of palm (tagua and chunga). There were tubers such as yuca (Manihot esculenta) and indications of maranta, though it is uncertain whether this corresponds to arrowroot (Maranta arundinacea). Clay figurines provide indirect evidence of other cultivated plants related to cotton (Gossypium barbadense) woven into garments; and coca (Erythoroxilum) which is represented being chewed by many of the mambeadores of Tulato people. In La Tolita, grains of carbonized maize were found in association with agricultural implements such as pestles, mortars and trapezoidal axes dated to about 2.350 A.P. Food and other products were transported in baskets of palm fibre; the effigy vessels known as canasteros demonstrate this practice not only in Tumaco but over the whole of south-western Colombia and northern Ecuador, a factor which has been interpreted as evidence for active long-distance trade between the coast and the Andean mountains.

Earlier evidence of pre-Hispanic agriculture has been widely reported from coastal Ecuador, especially the flood-prone lowland 
basins of the rivers Guayas, Daule and Babahoyo, where extensive areas of raised fields have been noted such as those of Samborondón, Peñón del Río (Durán), Taura and Colimes, among others. ${ }^{23,24}$ Further north in the province of Esmeraldas there is evidence of raised fields in the south of the Isla de la Tolita. ${ }^{25,26}$ In the Andean zone of southwestern Colombia raised fields were also used during the Yotoco period (2.000 B.P.); these are located in the flood-prone flat bottom of the Valley of El Dorado in Calima in the Western Cordillera. ${ }^{27}$ In northern Colombia, in the area of the lower river San Jorge in the Caribbean plains, are extensive remains of pre-Hispanic agriculture with raised fields covering more than 500.000 hectares of marshy terrain. The period showing highest population density (platforms and funerary mounds) and greatest construction of raised fields has been established between 2.150 and 1.500 B.P. According to the palaeoclimatic history of the region, this period corresponds to an epoch of high humidity. ${ }^{28}$

While there is no doubt that the economy of these coastal societies was based on agriculture, artisanal fishing was also very important. It has been claimed that maize, complemented by fish and shellfish, was the dietary staple underlying the demographic expansion of agricultural coastal societies..$^{29}$ It is probable that the canals regulating water in the fields were also exploited for farming fish, as is suggested for other archaeological sites; while artisanal fishing in the estuaries, marshes and open sea was highly productive due to ichthyological diversity. It is hard to study this kind of nutrition in Tumaco, as remains of fish and other species are not preserved in the archaeological record, hindering direct inference concerning the importance of fish in the diet of these coastal groups. There are abundant terrestrial and marine resources in the mangrove swamps and marshes which extend inland for some $10 \mathrm{~km}$, forming a salt- and fresh-water riverine network influenced by the tides. In these areas the bases of subsistence are identified from ceramic and lithic archaeological remains. Typical clay graters incrusted with microliths were used for various purposes, especially for preparing fish and grating foods such as yuca. ${ }^{30}$

On the open sea and in the estuaries, fishing and the collection of shellfish were complementary activities supplying the diet of these societies. Innumerable stone net-weights are found at sites in the mangrove swamps and in the interior of the river systems. R Cooke ${ }^{31}$ has claimed that artisanal fishing in the estuaries must have been relatively easy using small canoes, nets with stone weights and hook and line. Local knowledge of the habits and behaviour of marine and delta species must also have been important. Deep-sea fishing on the other hand required more complex equipment and more sophisticated technology than fishing in shallow tidal waters. Marine routes, marshes and rivers served as natural means of communication among the Tulato communities scattered over hundreds of kilometres along the coastline. At the same time, these routes were used to expand exchange networks for products and ideas between the coastal zones and the more distant Andean regions of the interior.

\section{Exchange networks and goods}

In Tulato times the Pacific coast provided innumerable subsistence resources in the form of raw materials from which goods of different kinds - personal, sumptuary, ritual, etc. - could be made. This would have created a surplus which led to important movement of commodities within the region and even to exchange between coastal communities and other populations in the high Andes. Exchange relationships from and to the Tumaco-Tolita region can be established along two routes:
(1) the coastal route, where sumptuary objects such as stone beads, shells (Spondylus sp., Strombus), stimulants (coca) and metals (gold, platinum) were exchanged, and

(2) the interior Andean routes, where gold, stones, woods (chonta), salt and coca were principally taken. From the Andean zones trade in at least one product, obsidian, can be recognized within this network.

The network as a whole indicates that those involved in exchange had access to a wide and varied range of products and raw materials. Some of these items could have been used as prestige objects for the elites, an important characteristic of societies of rank. ${ }^{32,33}$ Obsidian is a volcanic material from the Andes which was exchanged for lowland coastal products in response to stimulus and demand from the complex societies of both regions. From archaeological evidence in northern Ecuador we can sketch possible exchange routes between the mountains and the coasts of Esmeraldas and Tumaco. Evidence of exchange can be seen between the regions of Tumaco-Tolita and the east of Quito at the site of Jardín del Este, an area close to the principal sources of obsidian. ${ }^{34}$

\section{The decline of Tulato. other coastal cultural developments}

From 1,650 B.P. the Tumaco region and its surroundings experienced cultural changes which appear to indicate a crisis in the chiefly structures of the Tulato societies. The great cultural and technological advances of these societies are no longer perceptible, giving way to different cultural manifestations on the island of El Morro and in interior alluvial and fluvial zones. At this period no artificial mounds were constructed, the land was not worked with raised fields and ditches, nor was there any production of the characteristic pottery and figurines of Tulato societies. Later groups in Tumaco are represented by the Bucheli-Caunapí peoples, who settled in the forested lowlands. The typical pottery of these groups is simple and, in some instances, coarse, with globular and sub-globular jars and simple hemispherical or carinated bowls. Decoration consists of geometric motifs incised on the upper part of the vessels; there may also be red paint on the lip of the vessel, applied decorated strips and schematic representation of anthropomorphic figures. Most forms were made to be used in cooking, although it is noted that some larger vessels were used for secondary burial, a fairly widespread practice among the later groups of the coastal plain and Andean mountain areas. The communities were not very large, and their dwellings were dispersed along the rivers, occupying a humid tropical forest habitat. In view of the distribution of settlements we can establish that the economic resources of these groups would probably have been based on slash-and-burn agriculture, with maize (Zea mays) and yuca (Manihot esculenta) as the main products. Gathering, fishing and hunting activities in the ecosystems of the forested plain played an important part in the economy of these groups.

In terms of social complexity, the Bucheli-Caunapi may have attained tribal status, with egalitarian clans under local chiefs who were perhaps also shamans. Such leaders would have made decisions on behalf of the group and conducted ceremonies regulating social, economic and political stablility. ${ }^{35}$ Obviously, this level of social organization is not comparable with that of earlier periods on the Pacific coast of southern Colombia. The archaeological evidence correlates with egalitarian tribal societies occupying small nucleated settlements with scattered dwellings in marginal areas; burials are 
simple, often without grave goods; ceramic and gold objects are made in a rudimentary way. Lastly, exchange between groups is limited, their maximum sphere of influence extending to oblique contacts with societies of the western Andes, such as the groups of the high plains of Nariño and those of the high valley of Patía and Guachicono. ${ }^{36}$

\section{The archaeological heritage of the pacific coast}

In future research relating to the origin and development of the Tulato centres, we should concentrate on systems of exchange: their emergence and crystallization as well as their regional importance in terms of coast-mountain contact. More needs to be known about the mechanism of exchange routes: sources of supply, flow of goods, acquisition of raw materials, forms of transport, merchants and points of contact throughout the valleys and mountains of the Andes. In coastal areas we also need to know more about the control and circulation of exchange products, whether by sea or overland. We should also be rigorous in recording objects of exchange, whether these relate to the economy in terms of food products or sumptuary goods. Among their sumptuary goods, Tulato societies included metal objects. Unfortunately, many archaeological sites in Esmeraldas and Tumaco have been, and continue to be, the object of guaqueria (looting), a factor which has limited the development of comprehensive studies in the area. For the time being it is impossible to undertake a full analysis of the metallurgy of the region, as we can only count on a handful of systematically excavated finds, a larger number of metallographical analyses and a few reliable $\mathrm{C}-14$ dates; this in contrast to the huge quantity of archaeological objects, generally without any context at all, scattered throughout private collections and museums. It is true that we can study the formal technological aspects of the metals and in some cases infer their use and symbolism in accordance with the thinking of indigenous communities. However, the archaeological context in which finds appear is of vital importance for our inferences and interpretations. At present the Tumaco region is undergoing rapid urban and industrial expansion; there is however no indication of local plans to develop programmes of preventive archaeology, nor plans for archaeological management which might mitigate the loss of archaeological and cultural heritage. ${ }^{37-45}$

\section{Acknowledgments}

This study was made possible thanks to the Grupo Estudios Arqueológicos Regionales y Patrimonio, GEARP, Department of Antropology, University of Cauca; to Martha C. Hernández for her comments on this article, and to two academic colleagues; to Linda Mowat for the translation from Spanish into English.

\section{Funding}

None.

\section{Conflicts of interest}

Author declares that there is no conflict of interest.

\section{References}

1. Patiño D. Pre-Hispanic Tumaco: Settlement, Subsistence, and Exchange on the Pacific Coast of Colombia. Editorial Universidad del Cauca. Popayan. 2003.

2. Barona G. El combate de las morales. Editorial Universidad del Cauca. Popayán. 2004.

3. Romoli de Avery, Kathleen. Notes on the indigenous peoples of the Colombian Pacific coast at the time of the Spanish conquest. Colombian Journal of Anthropology. 1963;12:260-292.
4. Brumfiel EM, TK Earle. Specialization, exchange, and complex societies: an introduction". In Specialization, Exchange, and Complex Societies, EM Brumfiel, TK Earle, editors. Cambridge: Cambridge University Press; 1987;1-9.

5. Lightfoot K. A consideration of complex prehistoric societies in the U.S. Southwest. In: R Drennan, C Uribe, editors. Chiefdoms in the Americas, Lanham: University Press of America. 1987;307-323.

6. Reichel Dolmatoff G. Archeology of Colombia: An introductory text. Second Botanical Expedition Foundation. Arch lithograph Bogota. 1986.

7. Cieza de León, La crónica del Perú. Espasa, Calpe, Madrid.

8. Bouchard JF, P Usselmann trois millénaires de civilisation entre colombie et équateur. CNRS Editions. Paris. 2003.

9. Brezzi A. Tulato: ventana a la prehistoria de américa. Villegas Editores. Bogotá. 2005.

10. Bouchard J. F.1982-83 Excavaciones arqueológicas en la región de Tumaco, Nariño, Colombia. Revista Colombiana de Antropología. 14:125-334.

11. Cubillos, Julio césar costa pacífica historia, Prólogo de Duque Goméz, Luis. En Notas Arqueológicas Tumaco. Ed. Minerva. Bogotá. 1955.

12. Ugalde MF. Iconografía de la Cultura Tolita. FAAK 7. Reichert Verlag. Wiesbaden. Germany. 2009

13. Elevated pre-Hispanic fields in the Tumaco-La Tolita economy, Colombia's Pacific Coast. In: Camellones y Albarradas, Francisco Valdez, editors. Ancestral Agriculture. 2006;69-188.

14. Scott D. Thecnical examination of some gold wire from pre-Hispanic South America. Studies in Conservation. 1991.36(2):65-75.

15. Scott David, E Doehne. La soldadura con aleaciones de oro en la América antigua: un análisis de dos pequeños adornos adornos provenientes del Ecuador. Boletín Museo del Oro. 1990;29:52-61.

16. Fresco A. Aboriginal metallurgy in Ecuador. In: I Zapater, editor. Catalog of the Gold Room. Quito: Editions of the Central Bank of Ecuador.1995.

17. Plazas C, AM Falchetti. Cultural patterns in the pre-Hispanic goldsmith of Colombia. In Pre-Columbian American Metallurgy. 1986; 203-227.

18. Valdez F. La Tolita archaeological project (1983-86). Museum of the Central Bank of Ecuador. Quito: Editorial Luz de América. 1987.

19. Zapater, Irving. Catalog of the Gold Room. Quito: Editions of the Central Bank of Ecuador. 1995.

20. Wurster W. Architectural representations of Pre-Hispanic Ecuador. In Anthropology of Ecuador. Memories of the first European symposium on anthropology of Ecuador. 1989;8:61-78.

21. Stemper D. The persistence of prehispanic chiefdoms on the Rio Daule, Coastal Ecuador. University of Pittsburgh Memoirs in Latin American Archaeology 1993. p. 169-180.

22. Zeidler J, D Pearsall. Regional Archaeology in Northern Manabí, Environment, Cultural Chronology and Prehistoric Subsistence in the Jama river valley. University of Pittsburgh Memoirs in Latin American Archaeology No.8. Pittsburgh. 1995;6(4):376-377.

23. Parsons J. Pre-Hispanic crop fields with parallel ridges, in the Guayas river basin, Ecuador. Notebooks of History and Archeology. 1973;40:185-202.

24. Buys JE, M Muse, Arqueología de asentamientos asociados a los campos elevados de Peñón del Río, Guayas, Ecuador”. In Prehispanic Agricultural Fields in the Andean Region: Part I, WM Denevan, K Mathewson, et al. editors. BAR International Series. 359 (i).

25. Montaño MC. The Management of Natural Resources in Tolita in its Classic Stage. Presented at The Ecuadorian-Colombian Meeting of Common Cultures, Ecuadorian-Colombian Neighborhood Commission, Banco Central del Ecuador, Esmeraldas. 1990. 
26. Tihay JP, P Usselmann. Medio ambiente y ocupación humana en el litoral Pacífico Colombo-ecuatoriano. In: Mercedes Guinea, Jean F. Bouchard y Jorge Marcos, editors. Cultura y Medio Ambiente en el Área Andina Septentrional. Biblioteca Abya-Yala. 1995;21:377-399.

27. Cardale M, W Bray, T Gähwiler, et al. Calima: Diez mil años de Historia en el Suroccidente de Colombia. Fundación Pro-Calima. Bogotá: Editorial Printer Colombiana, Ltda. 1992.

28. Plazas C, AM Falchetti J, Saens, et al. The Zenú hydraulic society: an archaeological study of 2000 years of history in the plains of the Colombian Caribbean. Bogotá: Bank of the Republic. 1994;5(4):384-385.

29. Raymond SN, Van der Merwe, Julia A Lee-Thorp. Staple foods in Formative Coastal Ecuador: Maize, Manioc, Fish? 1993;14-18.

30. Ciudad, A. Ralladores y tapaderas de incensario. La cultura tiaone, editado por M. Rivera,. Ministerio de Asuntos Exteriores, Madrid. 1984;95-132.

31. Cooke R. Prehistoric nearshore and littoral fishing in the eastern tropical pacific: an ichthyological evalution. Journal of World Archaeology. 1992;6(1):1-49.

32. Gnecco C. Exchange relations and elite goods among the chiefdoms of southwestern Colombia. In: C Langebaek, F Cárdenas, editors. Caciques, Exchange and Power: Regional Interaction in the Intermediate Area of the Americas. Bogotá: University of Los Andes, 1995;175-196.

33. Salazar E. The exchange of obsidian in pre-Columbian Ecuador: theoretical-methodological perspectives. In: Latina today, G Politis, editor. Archeology in America Banco Popular Library, Bogotá. 1992. p. $116-131$.

34. Buys J, V Dominguez. La Arqueología de Cumbaya, Provincia de Pichincha, Ecuador. In: JF Bouchard, M Guinea, editors. Relaciones Interculturales en el Area Ecuatorial del Pacifico Durante la Epoca Precolombina. Oxford: British Archaeological Reports, International Series. 1989. p. 75-95.
35. Johnson A, T Earle. The evolution of human societies. Stanford University Press, Stanford. 1987.

36. Uribe MV. Relaciones prehispánicas entre la costa del Pacífico y el altiplano nariñense. Revista Colombiana de Antropología. 1976;20:11-24.

37. Fried M. The Evolution of Political Society: An essay in political anthropology. American Anthropological. 1969;71(3):507-509.

38. Power in Pre-Hispanic Societies in Colombia: An Interpretation Essay. Power on Stage. Pre-Hispanic Colombia. 2005;17-48.

39. Guinea M. Ecology and culture in the area of the mouth of the Esmeraldas river, Ecuador. In: Mercedes Guinea, JF Bouchard, Jorge Marcos, editors. Culture and Environment in the Northern Andean Area. Quito: Editorial Abya-Yala 1995;21:165-194.

40. Pre-Hispanic inhabitants of Cauca, Colombia. Anthropological Reports 1990;4:35-52.

41. Pre-Hispanic Settlements on the Pacific Coast of Cauca. National Archaeological Research Foundation, Banco de la República. Bogotá. 1988.

42. Goldsmithing and Shamanism. An iconographic study of the Gold Museum. Editorial Colina. Medellin. 1988.

43. Scott David A, W Bray. Fusion gilding and foil gilding in prehispanic Colombia and Ecuador. In C. Plazas, editor. Arqueología de las Americas. 1988. p. 319-334

44. Ancient platinum technology in South America, its use by the indians in pre-hispanic times. Platinum Metals Review. 1980;24:147-157.

45. Pastures and Protopastes: the regional network for the exchange of products and raw materials from the 10th to 16th centuries AD. Maguaré. $1986 ; 3: 33-46$. 